\title{
Preliminary investigations of a textile fabric used as support for a sarcophagus from Astra Sibiu Museum
}

DOI: 10.35530/IT.071.01.1622

\author{
IRINA-MARIANA SĂNDULACHE \\ ELENA-CORNELIA MITRAN \\ LUCIA-OANA SECĂREANU \\ OVIDIU-GEORGE IORDACHE
}

\author{
ELENA PERDUM \\ IULIA TEODORESCU \\ ANDREA BERNATH
}

\section{ABSTRACT - REZUMAT}

\section{Preliminary investigations of a textile fabric used as support for a sarcophagus from Astra Sibiu Museum}

Historical textiles are fragile and more prone to damage. Regarding this inconvenience, heritage sample analyzes are quite difficult to achieve primarily due to fiber degradation, secondly due to the complex composition (the samples can also contain metallic threads or some other components) and last, but not least, because of the microbiological degradation. The samples evaluated in this paper were used as support for a wooden sarcophagus containing an Egyptian mummy which is estimated to be over 2000 years old.

The purpose of this work was to carry out a preliminary characterization of the samples, using minimally invasive techniques. Thus, two types of methods were used: SEM evaluation and microbiological assessment. SEM analysis revealed that the constituent fibers for all the samples are natural fibers of animal origin: wool and alpaca fibers. SEM also provided information about the surface of the fibers and more than that, by using this equipment it was possible to visualize the degree of degradation most likely caused by the attack of insects and different types of fungi and bacteria. Bioburden isolation from the archaeological samples highlighted that the highest bioburden load was registered by sample $B$, followed by sample $C$ and sample $A$. After the screening it was concluded that all samples present both filamentous fungi specific structures and bacteria specific structures. The future studies will be directed towards obtaining more information by micro- or non-destructive methods.

Keywords: SEM, microbiological assessment, wool, alpaca, Egyptian mummy

\section{Investigații preliminare asupra unui material textil utilizat drept suport pentru un sarcofag de la Muzeul \\ Astra Sibiu}

Materialele textile istorice sunt fragile și, astfel, sunt predispuse la deteriorare. Având în vedere această inconveniență, analizele efectuate asupra probelor de patrimoniu sunt dificil de realizat, în primul rând din cauza degradării fibrelor, în al doilea rând din cauza compoziţiei complexe (probele pot conţine, de asemenea, fire metalice sau alte componente) și nu în ultimul rând din cauza degradării microbiologice. Probele investigate în cadrul acestui articol provin dintr-un material textil ce a fost utilizat drept suport pentru un sarcofag din lemn conţinând o mumie egipteană a cărei vechime este estimată la peste 2000 de ani.

Scopul acestui studiu a fost realizarea unei caracterizări preliminare a probelor, utilizând tehnici de analiză minim invazive. Astfel, două metode au fost selectate: investigarea cu ajutorul Microscopului Electronic de Baleiaj (SEM) și analize microbiologice. Cu ajutorul analizei SEM a fost dezvăluit faptul că toate probele au fost realizate din fibre naturale de origine animală: lână de oaie și de alpaca. Cu ajutorul SEM au fost obţinute și informaţii privind suprafaţa fibrelor și a fost posibilă vizualizarea gradului de deteriorare cauzată, cel mai probabil, de către insecte și diferite tipuri de fungi și bacterii. Analiza microbiologică a probelor arheologice a evidențiat faptul că proba $B$ a avut încărcarea microbiană cea mai mare, urmată de către proba C și proba A. În urma screening-ului a putut fi concluzionat faptul că toate probele prezintă atât structuri filamentoase specifice fungilor, cât și structuri specifice bacteriilor. Studiile viitoare vor fi direcţionate către obţinerea mai multor informaţii prin utilizarea metodelor micro- și nedistructive.

Cuvinte-cheie: SEM, analiză microbiologică, lână, alpaca, mumie egipteană

\section{INTRODUCTION}

In order to establish a correct and personalized protocol for the optimal maintenance conditions of the objects with historical and artistic value from museums, a thorough comprehension of the materials from which these objects are made of and their physical and chemical properties is imperious [1]. The aim of this scientific study is to present the results of a preliminary assessment of a textile fabric which has been used as a support for a wooden sarcophagus containing an Egyptian mummy which is estimated to be over 2000 years old.

\section{MATERIALS AND METHODS}

\section{Materials}

The sarcophagus containing the Egyptian mummy can be found at The Museum of Universal Ethnography Franz Binder, which is a department of the National 
Museum Complex ASTRA Sibiu. The three samples that were investigated come from different areas of the textile support for the wooden sarcophagus (figure 1). From the collective memory, the textile support was most likely introduced under the sarcophagus in the 1990s.

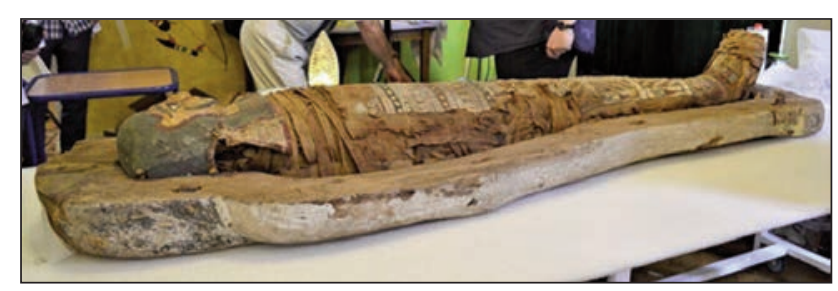

Fig. 1. The mummy within the sarcophagus

The samples collected from the textile fabric are presented in table 1 below. In addition to the three textile samples, the dust residue that was present in sample $\mathrm{C}$ was also analyzed.

Table 1

\begin{tabular}{|c|c|}
\hline \multicolumn{2}{|c|}{ THE SAMPLES AND THEIR APPEARANCE } \\
\hline $\begin{array}{c}\text { Sample } \\
\text { label }\end{array}$ & Sample appearance \\
\hline A & S \\
\hline B & \\
\hline C & \\
\hline
\end{tabular}

\section{Methods}

\section{Scanning Electron Microscopy (SEM)}

This method is widely used for the analysis of the morphology of fiber and fabric surfaces [2, 3]. For example, Cybulska M. et al. [4] applied this technique in the analysis of archaeological textile samples from the Roman period and the Middle Ages and they were able to identify the constituent fibers of the evaluated material.

Morphological investigations of the textile samples and the dust in sample $\mathrm{C}$ were performed using a $\mathrm{FEI}$ Quanta 200 Scanning Electron Microscope. For each textile sample, a very small piece was cut and then it was placed on a specimen stub using double sided conductive carbon tape and analyzed using the following parameters: accelerated voltage: $20.00 \mathrm{kV}$; detector: GSED. In the case of the dust from sample $\mathrm{C}$, the specimen stub covered with the double sided carbon tape was gently pressed onto the dust and analyzed using the same parameters as for the textile samples. All the SEM micrographs were taken using 1000X magnification.

\section{Microbiological assessment}

The three archeological samples were subjected to microbial isolation of main strains present on the fabrics. Approximately 5 grams of each fabric was chopped in smaller pieces (in order to maximize sample surface) and put in a volume of $300 \mathrm{~mL}$ sterile physiological saline solution with Tween 80 anionic detergent (Fisher Scientific, UK), a polysorbate surfactant which helps in the process of protein stabilization, allowing a proper dispersion of plated microbial cells (prior to incubation). Samples were agitated on a Promax 2020 shaker (Heidplph) for $5 \mathrm{~h}$ at $220 \mathrm{rpm}$, in order to dislocate the potentially existing microbial cells from the surface of the fabrics. Bioburden isolation was carried out on nine semi-synthetic nutritive media, as following: Czapek-Dox semi-synthetic media (Scharlau, Spain), used for cultivation of fungi, containing nitrogen as a sole source of nitrogen, frequently used for isolation of fungal species such as Aspergillus, Penicillium, Paecilomyces, Saccharomyces etc.; Potato-DextroseAgar (Scharlau, Spain) usually used for stimulating sporulation and growing of various fungi strains (species of Aspergillus, Saccharomyces, Rhodotorula, Geotrichum, Penicillium, Trichophyton etc.); MaltExtract-Agar (Scharlau, Spain), a classic culture medium for moulds and yeast (Aspergillus, Saccharomyces, Penicillium, Candida etc.), with a high quantity of sugar (maltose, glucose, sucrose) that allows excellent growth and additional necessary growth factors provided by the gelatine peptone; Sabouraud 4\% Dextrose Agar (Merck, Germany), a complex medium for cultivation and isolation of yeasts and moulds (Trichophyton, Microsporum, Geotricum, Penicillium), with a high concentration in dextrose, which promotes the formation of Conidia and Sporangia spores (combined with low $\mathrm{pH}$ value), as well as pigments of yeasts and molds, along with the inhibition of bacterial growth; Bengalrot-Agar with chloramphenicol (Roth, Germany), a selective medium for the enumeration of moulds and yeasts, with additional selectivity against bacterial growth, by the incorporation of the heat-stable antibiotic Chloramphenicol and glucose as incorporated fermentable carbohydrate source, with enzymatic digest of animal and plant tissues providing the essential vitamins, minerals, amino acids, nitrogen and carbon; Nutrient-Agar (Scharlau, Spain), a solid culture medium for general purpose use with less fastidious organisms; Muller Hinton Agar (Oxoid, United Kingdom), a medium usually used for the isolation of pathogenic Neisseria species, inclusion of starch ensuring that toxic factors found during growth will be absorbed, thus allowing the development of microorganisms that are present in very small inocula; Simple Gelose (Sanimed, Romania), simple structure media for the isolation and growth of certain strains of bacteria. Except for the Bengalrot, Nutrient-Agar, Muller Hinton and Simple Gelose medias, all other 
nutritive medias had a concentration of $1 \mathrm{~g} / \mathrm{L}$ chloramphenicol (an antibiotic first isolated from cultures of Streptomyces venequelae), for the inhibition of certain bacterial species. After samples agitation, $1000 \mu \mathrm{L}$ were taken from each shaking solution and plated in duplicates on each nutritive media. Plates were then incubated at $28^{\circ} \mathrm{C}$ for 7 days and inspected for microbial morphological development.

\section{RESULTS AND DISCUSSION}

SEM analysis was used to investigate the microscopic appearance of the textile fiber surface, the type of fibers within the material, the diameter of these fibers, traces of insect and microorganisms attacks and the artifact residues (figure 2).

Following the SEM analysis, it can be said that the constituent fibers for all the samples are natural fibers of animal origin. However, the diameters of the constituent fibers vary widely, ranging between 15 and 90 microns. Due to the different appearance of the scales at the surface of the fibers and the very wide range of diameters, it can be preliminarily concluded that the fibers come from two different species of animals. Most likely, the fibers with more prominent and higher scales are wool fibers [5] and those with finer and less delimited scales are alpaca fibers [6]. For all of the textile samples, the extensive degradation caused by insects was highlighted. The most common insects that are known for attacking wool and other protein fibers are the larvae of the Tineidae (clothes moth) and Dermestidae (carpet beetle), although members of other species may attack wool incidentally [7].

Bioburden isolation from the archaeological samples highlighted various degrees of microbial development, based on both the originating archaeological sample, and the nutritive media used (figures 3-5), with certain samples having a higher bioburden degree, in terms of species, compared to others.

The highest bioburden load was registered by sample B (with 11 highlighted plates), followed by sample C (with 6 highlighted plates) and sample A (with 5 highlighted plates). The screening highlighted that all samples present both filamentous fungi specific structures and bacteria specific structures, with the nutritive media used for fungi screening (Czapek Dox, Sabouraud Agar, Bengalrot Agar and Malt Agar) highlighting more fungi-like morphological formations than the three media used for bacterial isolation (Nutrient Agar, Simple Gelose and Muller Hinton). This separation was also strengthened by the presence of chloramphenicol in certain media, when compared to others that can also have a direct influence on the species of isolated strains.

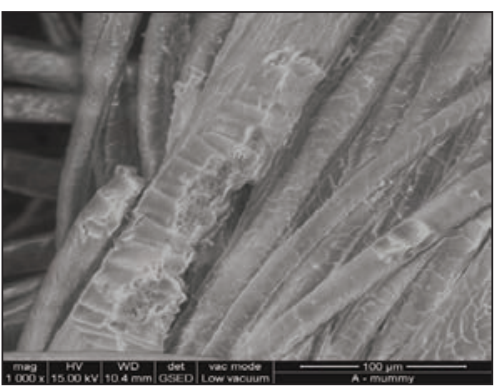

A

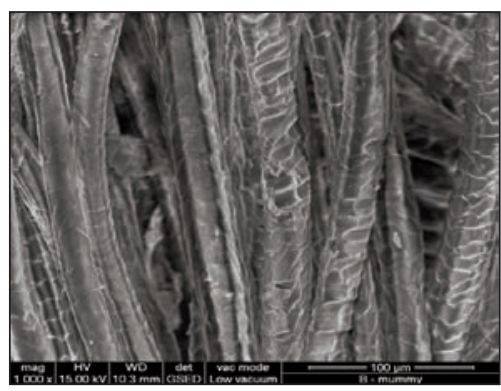

B

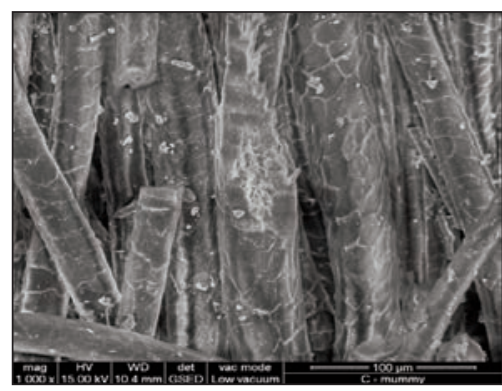

C

Fig. 2. SEM micrographs of the textile samples A, B and C, bar: $100 \mu \mathrm{m}$

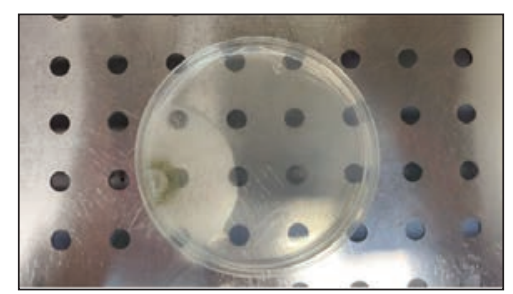

PDA

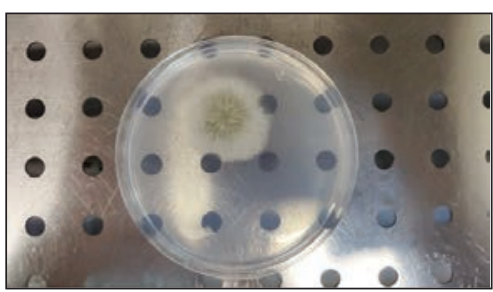

Czapek-Dox

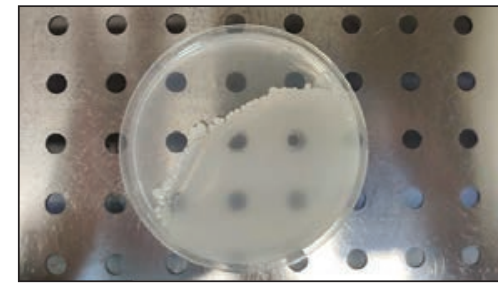

Nutrient Agar

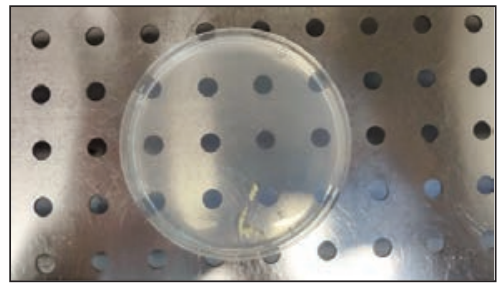

Simple Gelose

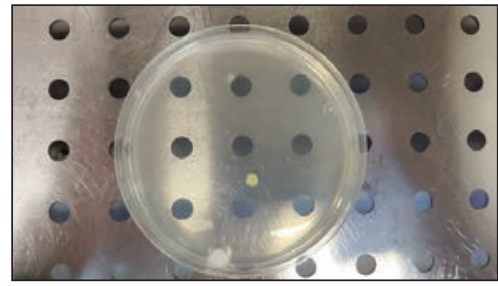

Muller Hinton

Fig. 3. Bioburden isolation from archaeological sample A 


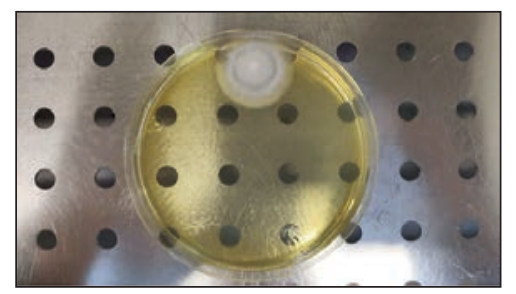

Sabouraud-Agar

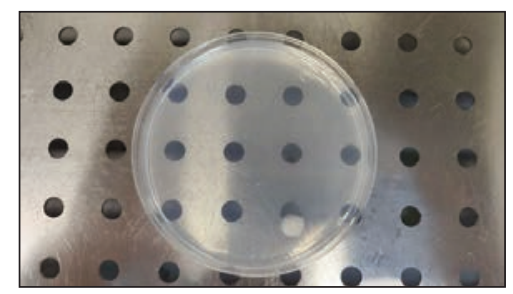

Czapek-Dox
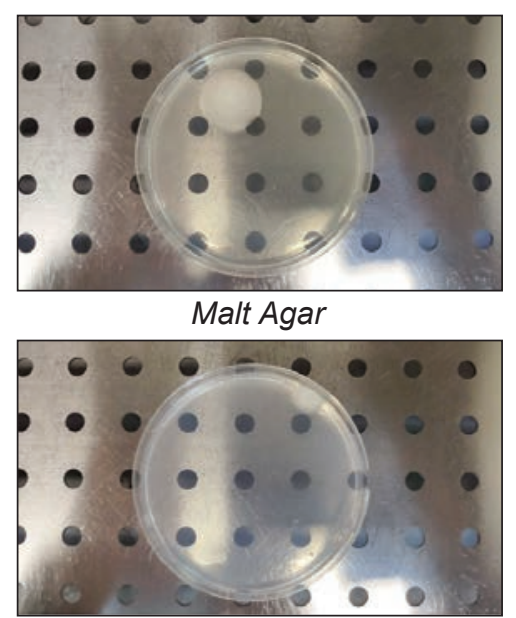

Czapek-Dox

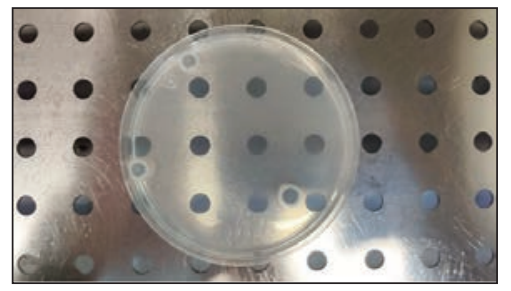

Simple Gelose

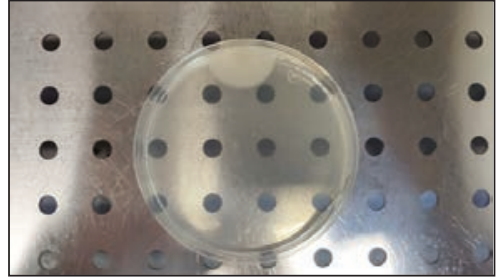

Potato Dextrose Agar

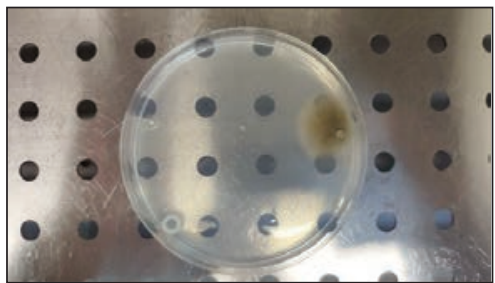

Simple Gelose

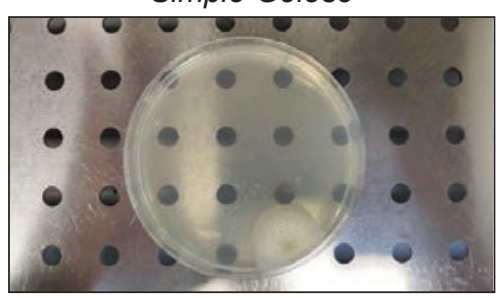

Muller Hinton

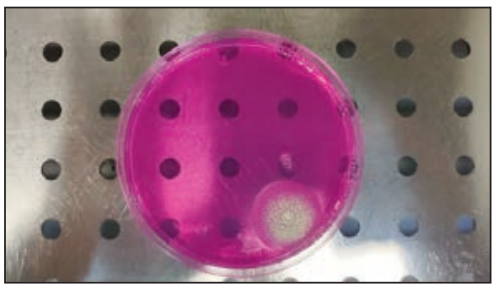

Bengalrot

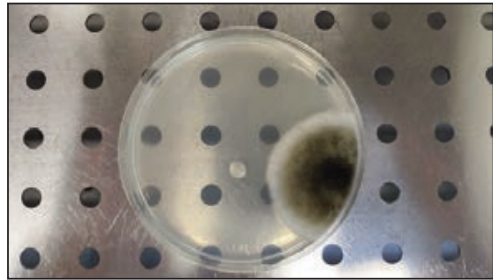

Potato Dextrose Agar

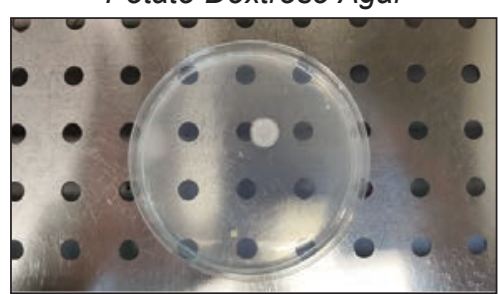

Nutrient Agar

Fig. 4. Bioburden isolation from archaeological sample B

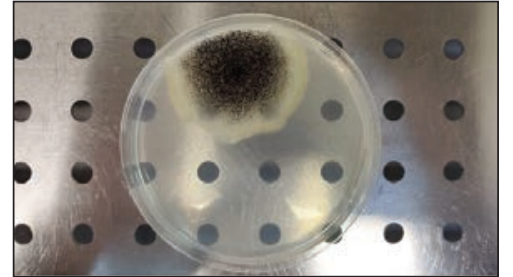

Potato Dextrose Agar

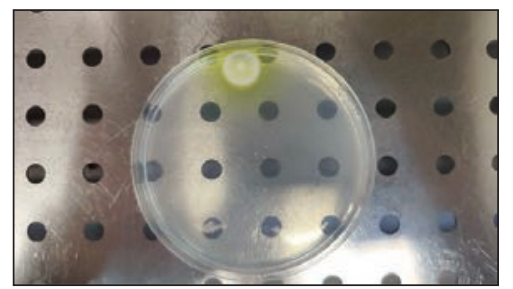

Nutrient Agar

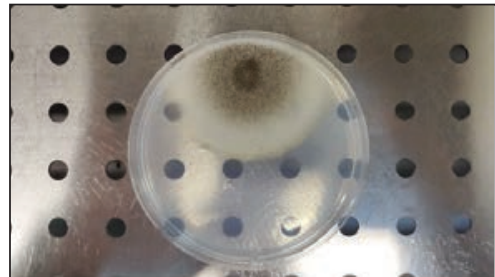

Czapek Dox

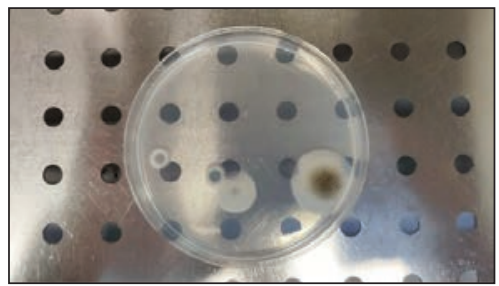

Simple Gelose

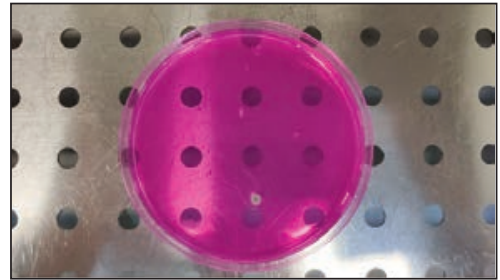

Bengalrot

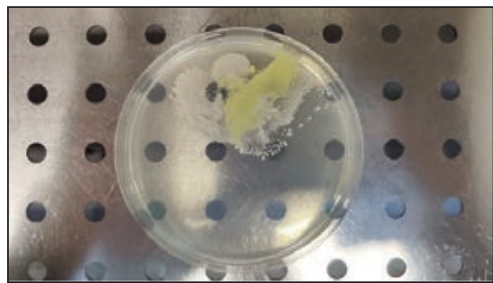

Muller Hinton

Fig. 5. Bioburden isolation from archaeological sample C

\section{CONCLUSIONS}

The results obtained after SEM analysis show that the constituent fibers for all the samples are natural fibers of animal origin. Due to the particularity regarding the diameters, appearance and the surface of the fibers, it can be preliminarily concluded that the fibers come from two different species of animals.
Analyzing other existing data in the specialized literature, an estimation of the type of constituent fibers could be made, namely wool and alpaca fibers. In addition to the evaluation of the fiber type, with SEM it was possible to visualize the degree of degradation most likely caused by the attack of insects and different types of fungi and bacteria. 
Bioburden isolation from the archaeological samples highlighted that the highest bioburden load was registered by sample $B$, followed by sample $C$ and sample A.

The conclusion of the screening is that all samples present both filamentous fungi specific structures and bacteria specific structures [8].

\section{ACKNOWLEDGEMENTS}

This work was elaborated through Nucleu Program, conducted with $\mathrm{MCl}$ support, project no. 4N/2019/PN 191705 01 . The publication of the paper is funded by the Ministry of Research and Innovation within Program 1 - Development of the national RD system, Subprogram 1.2 - Institutional Performance - RDI excellence funding projects, Contract no. 6PFE/2018.

\section{REFERENCES}

[1] Indrie, L., Oana, D., Ilies, M., Ilieș, D.C., Lincu, A., Ilieș, A., Baias, S., Herman, G.V., Onet, A., Costea, M., Marcu, F., Burta, L., Oana, I., Indoor air quality of museums and conservation of textiles art works. Case study: Salacea Museum House, Romania, In: Industria Textila, 2019, 70, 1, 88-93, http://doi.org/10.35530/lT.070.01.1608

[2] Peceliunaite-Baziene, E., The Textiles from Gintarai Cemetery, In: Archaeologia Lituana, 2002, 3, 75-78

[3] Abdel-Kreem, O., El-Nagar, K., Non-destructive methods to investigate the deterioration extent of coptic egyptian textiles, In: Journal of Textile and Apparel, Technology and Management, 2005, 4, 4

[4] Cybulska, M., Jedraszek-Bomba, A., Kuberski, S., Wrzosek, H., Methods of chemical and physicochemical analysis in the identification of archaeological and historical textiles, In: Fibers \& Textiles in Eastern Europe, 2008, 16, 5, 67-73

[5] Mathis, C.P., Faris, B., Guide B-409: Wool grades, Livestock \& Range Publications, College of Agriculture, Consumer and Environmental Sciences, New Mexico State University, 2007

[6] Tillman, A., Tillman, C., Surface Scanning Electron Microscopy of Suri Alpaca Fiber and Other Members of the Camel Family, In: Alpacas Magazine, 2006, 158-171

[7] Anderson, C.A., Hoskinson, R.M., Scanning Electron Microscopy of Insect-damaged Wool Fibers, In: The Journal of The Textile Institute, 2008, 61, 7, 355-358

[8] Bahtiyari, M.I., Yilmaz, F., Investigation of antibacterial properties of wool fabrics dyed with pine cones, In: Industria Textila, 2018, 69, 5, 369-374, http://doi.org/10.35530/IT.069.05.1516

Authors:

IRINA-MARIANA SĂNDULACHE ${ }^{1,2}$, ELENA-CORNELIA MITRAN ${ }^{1,2}$,

LUCIA-OANA SECĂREANU1 ${ }^{1}$, OVIDIU-GEORGE IORDACHE ${ }^{1}$, ELENA PERDUM ${ }^{1}$, IULIA TEODORESCU³, ANDREA BERNATH ${ }^{3}$

${ }^{1}$ INCDTP - National Research and Development Institute for Textiles and Leather,

16 Lucretiu Patrascanu Street, 030508, Bucharest Romania

e-mail: office@incdtp.ro

${ }^{2}$ Politehnica University of Bucharest,

1-7 Polizu Street, 011061, Bucharest, Romania

e-mail: secretariat@chimie.upb.ro

${ }^{3}$ ASTRA National Museum Complex, Sibiu, Romania

e-mail: office@muzeulastra.ro

Corresponding author:

ELENA-CORNELIA MITRAN

e-mail: cornelia.mitran@incdtp.ro 